\title{
AZ ÖRÖM NYOMÁBAN
}

\author{
KolOSAI NeDDA \\ az Eötvös Loránd Tudományegyetem Tanító- és Óvóképző Karának \\ adjunktusa \\ kolosai.nedda@tok.elte.hu
}

Szeretem az öszi félévet. Szeretem azt a lendületet, lelkesedést, erőt, amit az elsős évfolyam behoz az ELTE Tanító- és Óvóképző Karának épületébe. Beülnek első előadásukra a 200 -as nagyelőadó terembe: a szemekben csillogás, várakozás. Vajon hogyan őrizhető meg a hallgatókban egyetemi éveik során ez a lelkesedés? Még fontosabb kérdés, vajon a hivatásuk gyakorlása közben, az emberpróbáló mindennapokban kisgyermeknevelőként, óvodapedagógusként, tanítóként megőrizhető-e, hogyan örizhető meg a pályájuk iránti lelkesedésük, tudnak-e majd örömmel dolgozni? Évek óta motoszkál bennem ez a kérdés.

Winkler Mártával egy meleg, kora nyári napon találkoztam elöször személyesen, néhány évvel ezelőtt (2009-ben), Visegrádon. Akkoriban több kiváló tanítóval készítettem életút interjút, tapasztalatom lett az időpontok és helyszínek egyeztetésének algoritmusában. Márta telefonszámát többször kezembe vettem, majd amint meghallottam, milyen ütemben és hangosan dobog a szívem, le- leraktam a számát az asztalra, pihenni kicsit. Végre felhívtam. Azonnal úgy szólt hozzám, mintha egy évek óta folyó beszélgetés fonalát emelnénk együtt óvatos és gyors mozdulattal ujjaink közé. Sokkal korábbi időpontot javasolt, mint amit terveztem (álmodtam), a házat pedig könnyen megtalálom, mondta, a nagy nyárfáknál kell balra fordulnom. Szédítő, egyben megnyugtató a tempó, amit diktált és diktál. Azóta is minden találkozásunk és beszélgetésünk előtt ugyanúgy érzem az adrenalin molekulák jóleső áramlását, pupilláim tágulnak, jöhet az élmény.

Mártának jellegzetes és kifejező minden szava, mozdulata, pillantása. Márta közelében jelentéssel telnek meg a csendek, az Élet értelmet nyer, majd ezzel az értelemmel visszavonhatatlanul halad egy tartalmasabb, szebb kiteljesedés felé. A telefonban felhangzó első „Halló?!”-jában egyszerre van jelen a kíváncsiság és az, hogy jól tudom ám, ki vagy, a telefonáló személyének szóló öröm és a dörgedelem, hol voltál eddig, már vártalak.

Azon a bizonyos első találkozáson friss volt és nyitott. Egy pillantással felmért a szeme sarkából, megmutatta néhány kedves virágát, féltve őrzött, tanítványaitól kapott kincseket, majd letelepedtünk az interjúhoz. Márta csillogó szemekkel mesél, közben gesztikulál, a megfelelö dramaturgiai pillanatban picit hátraveti a fejét, rövid kacagását jellegzetes „Ha!” felkiáltás előzi. Egy évtizedek óta tanító barátom 
iskolájában néhány hónapja felkérésre előadást tartott a matematika tanításáról. „Márta megszólal, emeli a karjait, ahogyan játékba hív és bele lehet szeretni.” A háromgyerekes családanya meghökkentő mondata telitalálat.

Márta tehát mesélt és mesélt nekem az életéről: fegyelmezetten, összeszedetten válaszolt minden kérdésemre. Minden történetet, gyermekkori emlékeit tanítói hivatásának fényében értelmezett. Mint egy versenyparipa, aki már indulna, repülne, „szaladt előre” az időben, az emlékeiben a tanításhoz. Óvatos visszaterelgetéseim után már úgy fogalmazott „Amikor majd a tanításhoz érünk, elmondom neked...” Közben kint egyre lejjebb gurult a Nap, hüvösebb is lett, bizony én kértem töle szusszanásnyi szünetet, lazításnyi időt mindkettőnk érdekében. Az interjú 5 óra 44 perc, szorosan gépelve 48 oldalas lett. A vele készített interjúm tömörített szövege, az Ő kifejezései és szófordulatai mutatják meg legpontosabban Winkler Márta életútjának állomásait, valamint azt, hogyan értelmezi a tanítás szerepét az életében.

\section{Winkler Márta gyermekkora}

Szerencsés voltam, mert nagyon-nagyon boldog gyermekkorom volt a szerény körülmények ellenére. Vidéken születtem és éltem tizennyolc éves koromig, gyönyörủ emberi példákat, mintákat a láttam családban, ahol felnőttem. Anyukáék családját rendkívüli módon szerettem, kilencen voltak testvérek, kilenc fantasztikus ember, mindegyiküktöl lehetett kölcsönözni sok szépet, jót. Anyuka egyik testvérét Kassáról kellett hazavárni, ritkán örülni neki. Reszkettem érte gondolatban, boldog voltam, amikor végre megérkezett. Ö szólított engem egyedül Átának... Áta, ahogy ezt tudta mondani nekem! Csillogtam, ragyogtam, boldog voltam hetekig.

Mi mindig ünnepségre készültünk. Anyuka és a nővére hetekig készültek, gyönyörü asztalokat, ételeket készítettek nekünk, akkor, ugye hölgyek hímeztek, kiválasztották a legszebb anyagot. Karácsonyra együtt csináltak nekünk ajándékokat. A babaszoba bővült, dúsult minden évben, mind az ő munkáik nyomán. Az valami különleges élményem. Egyikőjük az asztalos munkákat készítette, másik testvér festette, együtt csinálták saját kézimunkával. Mi gyerekek, kicsi korunktól kezdve énekekkel, versekkel, olvasmányokkal készültünk. A névnaposok, születésnaposok között gyerek is volt mindig, csúfolódókat mondtunk egymásnak, vidám dolgokat csináltunk. Amikor iskolába jártunk, jöttek a többszólamú dallamok, amit együtt énekelhettünk, a komolyabb versek. Amikor már kicsit messzebbre kerültünk, a család akkor sem engedte el egymást. Gyönyörủ névnapokat ünnepeltünk.

Az édesanyám egészen különleges ember volt. Nagyon hamar tudta, hogy én gyerekek között fogok élni, előbb tudta, mint én. Állandóan összegyüjtöttem a gyerekeket és folyamatosan foglalkoztattam őket. Boldogan szerveztem iskolát, színházat, nagyon mozgékony gyerek voltam élénk fantáziával. Négyen voltunk testvérek, két lány két fiú. 
Az édesapám nagyon szépen énekelt, hajnalokig énekeltünk együtt. Rendkívül fontos volt, hogy a beszélgetéseiken is ott lehettünk, abból is tanultuk, hogyan kell felnőtteknek egymás között beszélgetni, élni.

Egyik nagynénémet nagy szemekkel figyeltem mindig, aki törékeny, vékony kis ember volt, nagyon szeretettem öt. Újságot olvasott folyamatosan és úgy vette föl a vita fonalát, hogy minden férfi tagja a családnak nagyon tisztelte őt. Jó példa, megélt büszkeség volt gyerekként, örültem neki. Jó volt hallgatni a magabiztosságot, a tudást, és azt hogy ő nem akart lehengerelni senkit soha. Vitatkoztak is - ők szegények két háborút éltek nagyon gyors egymásutánban -, de soha nem volt még csak szele sem annak, hogy elkomolyodna ez a vita, ö is nagyon tisztelte az embereket.

Anyuka nagyon sokat mesélt. Mindig sok vasalni való volt és reszkettünk ilyenkor az örömtöl, mert azt anya egyhelyben, végig énekelte, mesélte nekünk. Oda csoportosultunk. Én az asztal alatt szerettem ülni, az alatt, ahol ö vasalt és énekelt. Szerencsére sok-sok olyan szépen megélt epizód, gyönyörü élmények jellemzik a gyerekkoromat, amitől igazán gazdag lesz egy gyerek élete. Édesanyám a sok munka mellett tudott ránk figyelni. Verset megtanult nekünk rádióból, gyorsan lejegyzetelve, hozta, megtanította, könyveket kínált. A legtöbbet a mindig mindenkori jelenlétével adta. Ezt a hihetetlen biztonságot, hogy én itt azért vagyok, mert te itt élsz és én nekem az a dolgom, hogy jól élj. Ezt állandóan meg tudta üzenni, akkor is, amikor éppen nem örült annak, amit teszek. Végeredményben tőle kaptam mindent.

Kötelességem továbbadni az értékeket, amit tőle kaptam. Az emberszeretetet az egyik legfontosabb, valamint megmutatta, milyen a jó ritmusa az emberi életnek. Amilyen szeretettel fözött nekünk, meg pici korunktól volt saját munkánk, ami nőtt velünk mindig. Nagyon örült, amikor jót tettünk. Azért, hogy ezt az örömet kelthessem, mindent pontosan, precízen, gyönyörüen csináltam meg. Minden munkát szeretek, semmi nem nehéz nekem, meg semmi nincs olyan, amit nem szívesen teszek. Mindent az égvilágon. Szerintem ez a tulajdonság fontos egy tanítónak, ezzel tud üzenni a gyerekeknek; mindent megfogok, megcsinálok. De el ne térjek a tárgytól...

\section{Iskolás évek}

Még nem is voltam hat éves mikor már iskolapadban ültem, megszenvedtem, éretlen voltam még. Nagyon régen volt, a harmincas évek közepén. A nővérem által kipróbált tanítónőhöz kerülhettem első osztályban, rendkívül szigorú volt. Ennek ellenére én szerettem öt. Ám van olyan élményem, hogy vonalzóval elverte a kezemet, mert nem sikerült mindjárt a betüformázás, attól nagyon el voltam keseredve, folytak a könnyeim. Nem sírtam, nem csináltam jelenetet, nyeltem a könnyeimet. Tudom, hetekig hosszan foglalkoztatott engem, hogy egy tanító miért nem látja, azt hogy én ezt akarom, csak még nem tudom. Zokogva mondtam el anyuká- 
nak, hogy ez történt, de ugye ő nem haragszik érte. Megnyugtatott, dehogy haragszik, hiszen én már ezt így előszörre leírtam, legyek csak türelmes, írjam boldogan, mert az majd olyan szép lesz, hogy csuda lesz! Minden szépen elsimult, nem keltett ő ellentétet, tovább szerettem a tanító nénit. De szorongó voltam erősen szorongó. Tanítóként ezt is, nagyon tudtam használni ezt az élményemet. A tempóm lassúbb volt, mint a többieké, ezt nagyon megszenvedtem, mert én is mindig örömöt akartam haza vinni, és nem tudtam azt mondani: én voltam az első, én is tudtam.

Nagyon-nagyon érdekes dolog volt, mert kis mohón jó evő hírtelen evő gyorsan evő gyerek voltam és aztán többször fájt a hasam. Az iskolában pedellusunk volt, egy kedves házaspár, Mari néni és János bácsi. Odamehettem hozzájuk ilyenkor, ők melegítettek fedőt a pocakomra, meg odabújtam egy kicsit. Ez például nekem egy óriási dolog volt. Ezt már akkor nagyon értékeltem. Iskolai élményem még, hogy zongoráztam, de nagy csibész voltam, mert a diófára másztam fel a zongoraóra idejére elbújni. Élénk örökké táncolós éneklős voltam. Mai napig egyfolytában énekelek. Ezt majd az iskolai résznél is boldogan elmondom, hogy az iskolát mindig énekkel kezdtem, minden áldott napot.

Ötödik osztálytól nyolcosztályos gimnáziumba jártam, jó osztályunk volt, most is tartjuk a kapcsolatot, csak sajnos fogyunk erősen. Nagyon korán kosárlabdázni mentem. Ez is nagy élményem, egészen korán, a tízedik évemet súrolva egyesületben játszottam.

A gyerekkor hihetetlenül fontos! Egész életünk folyamán használjuk, amit ekkor gyüjtünk, minden tovább él bennünk, és ez jó. A rám bízott gyerekeknek mindig élményt, adtam, aminek örülni lehet. Egy embernek örülni, kell tudni!

Édesanyámban fantasztikus volt, ahogy az öröm képességét keltette bennünk folyamatosan. A titok, óriási dolog egy kisgyereknek, és folyamatosan voltak titkai, ez olyan csoda volt nekünk! Rádöbbenek, milyen sokszor mondom ezt a gyerekeknek; „Hú, ha tudnátok, hogy ebben milyen sok titok van!” A titok minden gyereknek nagyon kell, ugyanúgy, mint a játék az ének a mozgás. Ezek teszik gazdaggá, örömtelivé az életet. A mozgás az mindig egy örömélmény, az ének szintén. Játékosan megoldani valamit, jól viszi tovább az iskolai dolgunkat. Én mosogatáskor is tudok játszani az edényekkel. Tényleg mindent az égvilágon szívesen tudok csinálni. Mert belém épült, hogy játszva jól lehet megcsinálni és használom ezt a megélt tapasztalatomat a gyerekeknél.

\section{Megtalált hivatás - Élet a főiskolán}

Amikor rádöbbentem, hogy a tanítás az én utam, azon szívesen mennék, akkor volt pont egy év szünet, mert a középfokú tanítóképzőből felsőfokú tanítóképző lett, mi voltunk az első felsőfokú évfolyam. 1959-től 1962-ig jártam a Tanítóképző Intézetbe. Amikor fölvettek, rettentő boldog voltam. Akkor döbbentem rá, nekem nagyon fontos volt, hogy ide bekerüljek. Mivel egy pár év el is telt már, bizony nagyon tuda- 
tosan készültem a gyerekekre. A jó embereket kerestem a tanítóképzőben, és megkaptam a jó embereket.

Nagyon szerencsés voltam ebben is - mint a gyerekkoromban -, mert hihetetlen gonddal készült minden oktató. Bihari János tanár úr gyermekirodalmat oktatott, rajongva szerettem. Ott volt Ungváry Gyula tanár úr, aki matematika módszertant tanított, nagyon szerettem, nagyon sokat tanultam tőle, az ő ösztönzésére kezdtem el kísérletezni mindjárt, ahogy kikerültem az iskolából. Hernádi Sándor is ott oktatott akkor. Legnagyobb emberélményem Szijj Zoltán testnevelő volt, ő számomra a non plusz ultra. Töle a gyerekkel való bánásmódhoz szükséges gyakorlatot lestem el, hihetetlen szakember volt, a gyerek nagy tudója. Önképzőkört szervezett nekünk, ahol festményekröl ugyanúgy beszélgettünk, mint könyvekröl, regényekről gyerekekről, mert a tanítónak nagy a felelőssége abban, hogyan tud a gyerekekhez közeledni. Nagyon tetszett nekem, de vacogva mentünk be, mert csuda kérdései voltak.

Sokat hospitáltam Szijj Zoltán tanár úrnál, amikor elutazott, megkaptam a kicsi három éves óvodás csoportjának a helyettesítését. Nagyon örültem neki. Óriási örömöm volt, amikor tervezetet kellett írni, megrajzoltam, hihetetlen nagyot dolgoztam rajta és kitủnőt írt rá. Az ritka volt. Még most is meg van a dolgozatom ám! Óriási tisztelettel, igazi nagy szeretettel éltem ott a közelében. Nagyon-nagyon szerettem. Boldogan dolgoztam neki, hosszú órákat gépeltem, ott mellette, ő meg rajzolt kis pálcika embereket, azt is megtanultam jól tőle. Nem volt könnyü, könyveket írt, egyiket a másik után, de mindent lestem, hogy csak el tudjam tőle tanulni. Nekem a főiskolán azok az emberek kellettek, akiknél azt tapasztaltam, hogy tudatos benne, az hogy jó tanítót segítsen belölem. Nagyon sok szép élményem van, szerettem ott lenni. Örültem, amikor én vezényeltem egy ünnepélyen a gyerekkórust. Emlékszem, nem volt ruhám, a nővéremről húztam le valamit, hogy ünnepi ruhában tudjak menni a gyerekek elé. Azután népművészek jöttek, az étterem falát kifestették, úgy szerettem, boldogan nézegettem minden nap. Tóth Árpádné volt a biológia tanárnőnk, mi még kertészkedtünk is annak idején.

Még tanítóképzős hallgató koromban nagyon szerettem volna látni, mi az, hogy iskola. Kinek mit jelent az? Ki, hogyan fordul a gyerekhez? Mit jelent egyegy tanító számára, hogy ott él a gyerekekkel? Elkezdtem bekéredzkedni iskolákba, és ahova beengedtek, oda bementem bizony hospitálni. Saját szorgalomból, senki nem küldött. Kellett nekünk is mennünk tanítói gyakorlatra, de én elöbb elmentem már más iskolákba. Voltam a IX. kerületi iskolákban, meg voltam a belvárosban, az V. kerületben, a zenetagozatos Váci utcai iskolában, és az én keresgélésem, itt a jutalmát megkapta, mert az új matematikával kísérletező Varga Tamást találtam ott. Hú, ez kell nekem, gondoltam. Szaladtam Varga Tamás után, szegény nem tudott lélegezni már tőlem. Mert trolira fölszálltam, ha őt úgy fogtam el, az Országos Pedagógiai Intézetnek a folyosóján az ablakmélyedésekben faggattam; mondja nekem, mert én ezt nem tanultam, kérem szépen, én ezt csinálni szeretném. C. Neményi 
Eszternek odaadott engem, - mert ö már megunta ezt -, akkortól beletartoztam az ő bázis csapatába, a gyakorlati kipróbáló és bemutató voltam.

\section{Megtalált hivatás - Winkler Márta, a tanító}

Amikor végeztem a föiskolán nagyon-nagyon vágytam már gyerekek közé. Meg is érkeztem egy ezerfös iskolába, a Váli utcába, a Móricz Zsigmond körtérre. A 11. kerületi oktatási osztályvezető akkor - 47 évvel ezelőtt, 46 évig tanítottam, most szeptemberig, utolsó szeptemberig, már nem kezdtem sajnos - napközibe akart tenni engem. Mondtam neki, szépen kérem, próbálja meg, ne napközit adjon, nem, azért mert azt én lebecsülném, de én olyan sok mindent gyüjtöttem a gyerekeknek, hogy ha én ezt most nem próbálhatom ki, akkor én nagyon boldogtalan ember leszek. Azzal búcsúztam, nagyon sajnálom, én akkor ezt most nem fogadom el, megyek keresni máshová iskolát, ahol tanítani engednek. Mentem ki az ajtón és utánam szólt: „Márta, jöjjön vissza, adok magának osztályt.”

A világ legboldogabb embere voltam! 43 gyerekecském volt. Negyvenhárom. A világ legboldogabbja voltam. Ennyi gyerek ..., nem volt könnyü. 58 fös tantestület volt, 38 tanuló csoportja volt az iskolának. Ez hihetetlen nagy. Oda berobban egy fiatal tanító, aki kereteket kezd bontani. Leszögezett padok voltak, teljesen oda voltam tỏle. Hát borzasztó volt. 43 gyerek leszögezett padban, mozogni semmit nem lehet. A mozgás a gyerek életeleme! Hogyan lehetséges ez? Megláttam, amint a fizikai szertárból, - ez 4-5 évvel később volt csak - kihozták az öreg asztalokat, padokat, székeket, és akkor könyörögtem, az igazgatónak, hogy adja nekem azokat, addig könyörögtem, hogy megengedte. A szülökkel lecsiszoltuk, lakkal bevontuk, elmentem a méhbe, vettem gázcsöveket, lábtartót hegesztett rá az egyik szülöm, hogy a lábukkal ne harangozzanak a gyerekek. Egy katonaládám volt - híres volt a Váli úti iskolában -, az egész iskolát elláttam belőle szerszámokkal. Precizitásomból adódóan nem bírtam ki, hogy nekem ott ne legyen meg mindenem, ha én valamit a gyerekekkel csináltam, akkor ott van és én nyúlok érte. Teli voltam dobozokkal is, meg zsákokkal is, amiben bőrhulladék, textília, kóc, szerszám lapult.

Testnevelés órát, egyet el nem mulasztottam életemben. Nekem is olyan mozgás igényem volt, természetesen a gyerekét is megtartottam. Fonalat húztam ki, léggömbökkel zsinórlabdáztunk az osztályteremben. Kitaláltam gyakorlatokat a padokon. Minden testnevelés órámat megtartottam. Míg nem észrevették a testnevelők, hogy a tovább menő osztályaimmal lehet dolgozni, mert szeretik a mozgást. Veszekedtek a gyerekeimért. Komoly, nagy duzzogások voltak. Már jöttek elöre, hogy „Engem kérj az osztályodhoz...” nagyon boldog voltam. Később, kaptam kisebb termet is már. A nagy tornaterembe beférkőztem kosárlabdázni, volt kosárlabda kölyökcsapatom hosszú évekig.

Én 4 évig akartam vinni a gyerekeket - első osztálytól negyedik osztályig -, és kibirkóztam magamnak. Mindig nagyon komolyan mondtam, hogy ezt a 4 évet 
nem szabad akárhogy élni a gyerekkel, mert ez egy életre készíti öket arra, hogy szeressenek tanulni, boldogan gyüjteni ismereteket, meg jól élni egy közösségben.

A szülőkkel mindig jó kapcsolatom volt. Eleinte azt mondtam én magamnak, mit nekem szülő meg az eddigi élete a gyereknek, itt vagyok én, teszem a dolgom. Azután nagyon hamar szépen visszahúzódtam a csigaházamba, mert ráeszméltem; tudnom kell, mi történt a gyerek eddigi életében, mit tudok folytatni, mi az, ami még nincs, és én nekem kell adni. A gyerekeken keresztül engem a szülök nagyon elfogadtak. Látták, hogy változatos életünk van, hogy nagyon sok mindent csinálunk, érezték, hogy nagyon szeretem a gyerekeiket. Gyönyörü farsangokat csináltam nekik, gyönyörü betlehemes játékokat, de olyat, hogy megépítettük ott bent az osztályban, szép népi játékokat, regöléseket játszottunk el, fantasztikus volt. Az Iskolapéldában benne van egy ilyen betyár farsangoló, meg Arany János Fülemüléje.

Szerettem volna megmutatni, igazából hogyan is képzelem el az iskolát. Ez pont 1988-ban volt lehetett érezni, a változás szelét. Akkor egy emberpróbáló időszak után, sokáig sétáltam, hazamentem és azt mondtam Mihálynak, „Iskolát akarok csinálni.” Azonnal azt válaszolta, mindenben segít, költségvetést készített, pályázott nekem rengeteget. Ez egy boldog időszak volt! Óriási az embernek a hátországa. Meghatározóan fontos volt, hogy a férjem mindenben nagyon-nagyon segített engem. Büszke volt rám, hogy ennyire akarom ezt az iskolai munkát, szerette, hogy ilyen módon tudom élni ezt az egészet. Ez Mihálynak is nagyon fontos volt, mert ő is egy elhivatott ember volt a saját szakmájában. Amikor megkaptam a pályázati összeget, azt hittem, hogy a világ leggazdagabb embere vagyok. Semmink nem volt. Akkor elkezdtem a helyet keresni, még pincéket is megnéztem, és akkor találtam egy óvodát, amit éppen bezártak - XI. kerület, a Fogócska utca 6. -, és azt ott elkönyörögtem, hihetetlen nehezen. A régi tanítványokkal kitakarítottuk az óvodát, leszedtük a kis matricákat. Roncs bútorokat kivittük, bútoraink sem voltak, kölcsön bútorom volt egy darabig. Gyönyörü szép időszak volt! Akarták, hogy benépesítsem mindjárt a négy termet, mert azt nem lehet, hogy üresen áll. Azt mondtam, hogy nem, mert folyamatosan vagyok hajlandó építkezni. És hála Istennek az is sikerült, a tanítókat is megtaláltam. A tanítónál a gyerekhez való viszonya a döntő. Nagyon fontos az is, hogy az élete rendben legyen, a lelke nagy részét tudja adni, mert egy tanítónak úgy kell élni a gyerek között, mint egy szülönek. Ott nincs mese. Mint egy jó anyának, apának. Az induló csapatom nagyon jó volt. Gyönyörü szép évek következtek.

Loholtam az iskolába mindig, minden nap boldogan keltem, boldogan rohantam oda, az mindig egyforma volt. Mindig az izgatott, vajon az aznapra készített ötleteim, hogy fogannak meg, kell-e a gyereknek vagy nem. Kell-e, örül-e majd neki? Meg tudjuk-e csinálni? Volt, mikor nem tudtam elaludni, mikor nem jött be a feladat, módszer, amit én jónak tartottam, érdekesnek, szépnek a gyerek számára. Nagy szerencsém, hogy a gyereket meg tudtam örizni magamban. Mindig ott voltam én - a konfliktusmegoldásban, a játékban -, mint gyerek. Mit tennék, hogy tenném, most miért nem akarja elfogadni, mi az, amiért most benne ez egy nagy 
gond. Az, hogy a gyerekeket nagyon éreztem, ez az én nagyon jó gyerekkorom és a nagyon tudatos felkészülésem eredmény, ez biztos.

Nagyon-nagyon szép reggeleim voltak, azt óvtam, megtartottam mindig. Mihály hozta nekem a kávét, kedvességgel vett körül. Lassan, szépen elöjöttem a teljes előkészülésig, egy teljes óra kellett nekem, hajszálpontosan hétkor kiléptünk mind a ketten. Én mindig korán bent voltam az iskolában. Minden iskolában. Átöltöztem, abszolút kényelemben, hogy a gyereken semmit le ne töltsek, egy szoros cipöt, kényelmetlen ruhát, én mindig kívül hagytam, minden egyebet. Összes kínomat, fájdalmamat kívül tudtam hagyni, mert a gyerek volt a fontos. Holott sosem akartam elrejtőzni elölük. A véleményemet a pillanatnyi rossz állapotomat, azért azt ők mindenképp tapasztalták, el is mondtam, ha kellett.

Körbeszaladtam az iskolát, megbeszéltük az iskola titkárnővel az aznapi dolgokat. Konyhások helyükön, takarítók helyükön, mindenki bejött-e? Háromnegyed nyolckor beléptem az osztályomba minden alkalommal. Délután 1 óráig engem hívni telefonon nem lehetett. Hiába voltam vezetöje az intézetnek. Csak órák után. Visszamentem és akkor megint 3 órát - sokszor többet -, intéztem az iskola ügyeit. Bizony 4-5 óra volt, amikor én hazaértem, hát egyszer-egyszer később is az értekezletek, összejövetelek miatt. Sokan kérdezték, hogy mikor van időm és, hogy mennyit készülök? Sokat készültem mindig, a hazafelé úton figyeltem az embereket az utcán, villamoson, autóban akárhol, gyüjtöttem az élményeket. Megvolt másnapra a tollbamondás szövege, matematikából a szöveges feladat mindabból, amit láttam, tapasztaltam. Szombatonként mindig fáradt voltam, ahhoz, hogy készüljek, ezért vasárnap készültem a következő hétre végig, hogy el tudjam látni az adminisztrációs, meg vezetői feladataimat is, meg az első mindig az órám volt. Az elé nem helyeztem semmit soha.

Fontos nekem, hogy nyitott ajtónál tanítottam a Váli úti iskolában, és itt is a saját iskolámban. Már szinte mindenhol találkozom olyan emberrel, aki azt mondja, volt nálam, hospitált nálam, órát látott, külföldiek is jöttek sokan. Szlovákok, szerbek, horvátok, angolok és finn tanítók, nagyon szerettem őket.

A tanítás az életemben a legfontosabb. Semmiben nem tudtam volna ilyen boldog lenni. Végeredményben én mindig fürödtem az iskola adta örömökben. Egyedül vezettem az iskolát. A lelkiismeret-furdalás is odajött, mert sok időt elvettem Mihálytól, de sokat is vittem haza az iskolai örömből. Úgy summázom, hogy így kellett lenni, így volt jó, mert én így tudok boldog ember lenni. Elfogadom, hogy mindnyájunknak el kell menni, közös a sorsunk. Nem panaszkodhatom, de nem szívesen veszem, hogy még eggyel több ránc, már nem tudok olyan igazi, nagy energiával menni, haladni. De ma is sok mindent viszek, egyszerre kétszáz szálam van, mindig tudom, melyikhez kell lépnem, szólnom.

Szeretnék könyvet írni, továbbadni valami kis hasznot, hogy kicsipegethesse, az, akit érdekel. Mert nagyon érdekelt mindig a gyerek indulása, az alapozás, és hihetetlen sok tapasztalatom van, mennyire érdemes, mert a gyerek egyszer csak va- 
lóban hozza... Lélegzetem is eláll... Nem hiszem, hogy létezik olyan ember, akinek nincsenek kátyúi. Vannak megtorpanásaim, de ki tudok jönni ezekből a kátyúkból. Megépítettem magamban egy kis szerkezetet, ami tovább tud lendíteni. Sajnos, sokan nem tudnak kikapaszkodni belöle, azokat sajnálom. Nekik, ott szeretnék segíteni. Van ilyen több is, ahol segítenem kell. Érdemes volt, azért fohászkodom, hogy a gondviselés engedjen még mindent végig vinni, ami emberhez közeli, a folyamatnak ez a leszálló ága, ezt tudomásul kell venni, legyen értelme mégis. De nem vagyok olyan megelégedős, mert még mindig tovább- és addig keresem azt az utat, amíg meg nem találom. Megküzdök magammal ebből a szempontból is, de tudatos bennem, hogy küzdelem nélkül semmi nincs, érdemes küzdeni még mindig. Oda eljutni, az is egy harc. Oda, hogy most már elég volt. Már megvan annyi tartalom benne. Jó, még azt is szerettem volna, meg azt is..., de megvan a mai tartalom.

Most, hogy mindezt átgondolom és papírra vetem, - ahogyan apró mozaikokból, élmény töredékekből alkotom saját narratívámat Winkler Mártáról -, értem meg, hogy megtaláltam, akit mindig is kerestem. Amikor Mártát hallgatom, mindig tudom, hogy ez egy fontos pillanata az életemnek. Legtöbbször könnyed és játékos. Amikor a tanításról, tanítványairól beszél, komoly elszántság, mély, összpontosított figyelem ül ki az arcára, mint egy tudósnak, aki a világegyetem keletkezésének titkát fürkészi és éppen meglelte. Találkozásaink, rövid telefonbeszélgetéseink után is azt élem meg, hogy jobb emberré váltam.

Márta egyszerre ünnepélyes, tiszteletteljes és izgatott, amikor tanítványairól, gyerekekröl mesél. Egészen olyan, mintha 5 centiméterrel megnőne, ahogyan valóban magasabbra emeli ilyen alkalmakkor a fejét, kihúzza magát. Sok tanítóval találkozom, Márta ebben különleges. Amikor pedig a tanításról, tanítási módszereiről beszél, magyaráz, visszatérő szófordulata: „Miért nem lehet ezt megérteni?” Tenyerei összecsattannak, jobb kezének mutatóujja néhány jelentőségteljes pillanatig az ég felé mutat. Évezredek óta ez a tanító mozdulata, az ókori hieroglifákon a tanítás írásjele.

Márta 46 év tanítás után, jelenleg is aktív, könyvet ír, előadásokat tart, folyamatosan továbbadja mindazt a tudást, élményt, örömöt, tapasztalatot, amit felhalmozott tanításról, a tanítói hivatásról. A tanítóképzés felvállalt feladata a mediálás, Winkler Márta szemléletét megmutatjuk filmeken, valamint tart személyesen elöadásokat, szemináriumi beszélgetéseket az ELTE TÓK hallgatóinak. Többször kérdezték hallgatóim „Hogyan tudtam rávenni Mártát, hogy eljöjjön?” Ilyenkor szembesülök azzal, milyen kiváltságos helyzetben van, aki valóban ismerheti Mártát, és tudja, számára tanító- és óvodapedagógus hallgatók közé jönni nem feladat, hanem öröm és kihívás. Minden egyes ilyen alkalomra izgatottan, átgondoltan, szívvel-lélekkel készül - ez az Ö egyik lényeges tulajdonsága -, pedig elegendő lehetne, 
hogy válaszol a feltett kérdésekre, élő történeteket mesél az életéről, tanítói hivatásáról. Ám Márta elegánsan, szinte ünnepélyesen, felkészülten jön. Belépés elött gondosan elrendezi a külsejét, fejében az előre átgondolt terv és vázlat, kezében fénymásolt versek, kiolvasók, mondókák. Azután teljesen eltér eredeti terveitől, ami természetes, hiszen hitvallása, hogy a tervek, a tanítói vázlat arra való, hogy legyen mitől eltérnünk. De mindig kell, hogy legyen vázlat!

Azután elvarázsolja a hallgatókat. Hiteles személyiségén, életútján keresztül értelmet, jelentést nyernek a sokszor ismételt elméleti tézisek, egyben kiegészülnek soha nem hallott tartalmakkal, soha nem tapasztalt szemlélettel. A találkozások utáni hallgatói visszajelzések tanulságosak, megerősítőek, rendkívüli hatása van egyetlen Mártával töltött órának is. Néhány szubjektíven kiemelt visszajelzést csokorba gyüjtöttem. „Sokat tanultam már arról, hogy fontos a játék, de most már biztosan tudom. A legfontosabb, hogy figyeljünk egymásra és tanuljunk egymástól." „Az eltöltött másfél év alatt az egyik legélvezetesebb, leginteraktívabb órákat tölthettem el. Tanultam és tapasztaltam egyszerre.” „Az az érzés jön vissza, hogy ha jó a tanító, szinte bármilyen tárgyat meg tud a gyerekekkel szerettetni. Én szerelmes lettem a tanításba.” „Tetszett Winkler Márta módszere, személyisége, és az, ahogyan a tanárnő beszélt róla. Egyértelmü volt a tisztelet, csodálat és szeretet, mégsem próbálta ránk erőszakolni az ő módszerét. Így talán még közelebb kerültem hozzá.” „... szerintem mi mindannyian játszani fogunk a gyerekekkel!” „Örülök, hogy megismertem Winkler Márta tanítónőt és az ő szemléletét. Fontos számomra, hogy így is lehet tanítani (és így kellene), rengeteg türelemmel, játékkal.” „Örülnék, ha az én gyerekem egyszer majd ilyen tanítóhoz, ilyen iskolába járna.” „Lendületes volt, sokrétü, belefeledkeztem. Élmény volt jelen lenni és játszani, maradandó, vicces, intelligens." Márta ezek után az alkalmak után köszönetként, ajándékként, neki írt verssorokat, kézzel készített madarat, elénekelt éneket kap a hallgatóktól. Mert annak örül.

Winkler Márta számomra Az ember, A tanitó, hivatalos elismeréseit, díjait megjegyezni nem tudom, amikor szükséges, kollégáimtól kérdezem meg, közben arra gondolok, ha mindezek tudatában beszélnék vele, talán újra megijednék. Munkájának elismeréseként, a magyar oktatás megújításában vállalt kezdeményező szerepéért, a közösség érdekében kifejtett eredményes, érdemes munkájának elismeréséül, a matematika népszerüsítéséért, valamint a gyermekközpontú szemlélet közoktatásban történő meghonosítása érdekében végzett tevékenységének elismeréseként megkapta; az Apáczai Csere János-dijat, az Eötvös József-díjat, a Beke Manó-dijat, az Újbuda-dijat, a Budapestért-díjat, valamint a Magyar Köztársasági Érdemrend Tisztikeresztjét.

Számomra abszolút példakép. Minden tekintetben. Amikor a kora felöl érdeklődnek tőlem az emberek, mindig igazat mondok széles mosollyal: „Nem tudom!” Négy éves tanítói munkáját bemutató filmjén, az elsősökkel szalad, a negyedikeseknek a földön térdelve segít a csoportmunkában, az a 46. éve annak, hogy tanító. 
Megesett, hogy kellő finomság híján rákérdeztem a korára, olyankor mélyen a szemembe nézett, halkabban fejezte be megkezdett mondanivalóját, majd élénken új témába kezdett. Értem én.

Jó lenne ilyen elhivatott, örülni tudó, örömöket osztó, energikus, egyszerre nagyon tiszteletre méltó, mégis mindig játékos embernek maradni, mint amilyen Winkler Márta.

Amikor az óráimra készülve beállítom Márta aktuális filmjének részletét, a lányaim kórusban mondják: „Kérlek, tekerd vissza, szeretném megoldani ezt a feladatot!" Micsoda? Szeretnének megoldani matematika feladatot? Ez tényleg a legnagyobb elismerése a tanítónak! Máskor nem értettem mi is a problémája egy felnőttel hetedikes nagylányomnak. Elmagyarázta. „Tudod anya, ő nem olyan, mint Márta, öt nem érdekli, mi miért mondtuk úgy, miért gondoljuk úgy..."

Mindig kíváncsi, minden helyzetben tanul. „Ezt most tanulom tőled!” mondja teljes komolysággal, valódi figyelemmel. Úgy vezet autót, ahogyan él és tanít: remekül, lendületesen, átgondoltan. És végül mégis megáll a piros lámpánál. Ebben az egyben tehát találhatunk eltérést: az életben, a tanításban Mártát nem állították meg a piros lámpák.

Nagy büszkeségem - így utólag -, az a történet, amikor doktorandusz koromban, egy egyetemi könyvtárban úgy mutattak be: Kolosai Nedda, Winkler Márta kutató. İgérem, megpróbálom megfejteni, kikutatni, azonnal továbbadni hogyan lehetséges ilyen tanítóvá válni, mert minél többet látok belöle, annál jobban foglalkoztat, vajon mi Winkler Márta titka? 